Vol. 8, No. 2, 2021

https://doi.org/10.23939/eem2021.02.008

UDC 338.484.2

JEL Classification Code Z31

Olena Chernega

Kyiv National University of Trade and Economics, Ukraine, Postgraduate student E-mail: chernehaelena@gmail.com

ORCID ID: 0000-0003-4638-0398

\title{
ASSESSMENT OF THE COMPETITIVENESS OF THE TOURIST DESTINATION
}

\begin{abstract}
The tourism industry, which has shown exceptionally high rates of development in recent decades in the world economy, allows tourist destinations, which usually have limited resources for industrial development, to achieve income levels in industrialized regions, and with a balanced and effective government policy even overcome the effects of socio-economic crises. individual countries. One of the conditions for the successful existence of a tourist destination is the need to constantly monitor the level of its competitiveness by various criteria to identify strengths and weaknesses and, accordingly, to develop tactics and strategies for the development of the industry at different levels of management. The main criteria for the competitiveness of the destination is the compliance of the main tourist product of the territory to the needs of consumers. Various methods are used to assess the potential of tourist destinations, based on the defined capacity of the territories and the relationship to its potential, the load on resources and infrastructure, the definition of climatic, natural locations, economic indicators, etc. The definition of methods as a result of competitive analysis is the basis for building a reputable strategy for the development of the destination and subsequent vectors of positioning and the tourist world arena. Namely, it is expressed in the fact that as a result of the measures taken to manage the reputation management of the tourist destination, the competitive environment improves, the market develops, the infrastructure improves, which leads to the competitiveness of the tourist destination.
\end{abstract}

Key words: reputation management of a tourist destination, competitive tourist destination, tourist destination, reputation of a tourist destination

\section{Formulation of the problem.}

Consideration of the competitiveness of a tourist destination is of interest to different categories of users of this information. For state bodies of tourism management (Ministry of Economic Development and Trade, which includes the Department of Tourism and Resorts) assessment of the competitiveness of a tourist destination is important in terms of prospects for the development of this destination, comparative characteristics of the competitiveness of destinations [15]. Regional tourism authorities, having received an assessment of the competitiveness of a tourist destination, can use it in developing a strategy for destination development, identifying "bottlenecks" for tourism development, in developing tourism development projects in this destination. Potential investors who consider tourism as one of the possible areas of investment can use the assessment of the competitiveness of the tourist destination when making investment decisions.

\section{Relevance of the chosen topic}

The reputation of a tourist destination is formed under the influence of many factors and gives a holistic understanding of the visual perception of a tourist destination and its competitiveness in the world market. Accordingly, and a steady increase in tourist flows. According to WTO experts before the global tourism pause caused by the pandemic, the WTO in 2018, the total annual growth of tourist flows varied by an average of $7 \%$, and revenues from them - about \$ 1.6 trillion. For national tourism as a destination, there were less positive trends. According to the State Border Guard Service for 9 months of 2018 , Ukraine was visited by $+6.5 \%$ of foreigners and stateless persons more than for the 
same period in 2017. But it should be noted that for the 1st half of 2019 there was a slight decrease $(-5,6 \%)$ the number of entries from border countries, compared to the same period last year. This is explained by the fact that the leaders in the number of entrances of foreigners to Ukraine have historically been border countries, the share of which since 2018 is gradually decreasing from $85.5 \%$ to $80.7 \%$, which, among other things, due to the introduction of 01.01.2018 amendments to the Customs Code of Ukraine, which significantly limit the duty - free crossing of goods across the border [7]. Nevertheless, in 2019, Ukraine was visited by 14.5 million tourists, and in 2018 - 14.4 million. These are WTO data [3]. Although growth is observed, but very small. This indicates that the reputation of the regional national tourist destination, in turn, is poorly developed and has weaknesses. In addition to the imperfect political and economic situation and the current state of the global pandemic, there is a lack of effective tourism strategic planning, insufficient brand promotion and, as a result, unrecognizability, regional fragmentation and lack of integrity. This is also confirmed by the statistics of the World Economic Forum for 2019, where according to the index of tourism competitiveness of tourism, Ukraine ranks 78th place out of 140 positions, between Sri Lanka and Armenia. While in 2017 it took 88th place [4]. In recent years, there has been a trend of low ratings. From this we conclude that the reputational management of a regional tourist destination is quite low and uncompetitive, despite the rich potential and resources of the country, and no less promising tourist destination on the tourist map of the world than European tourist destinations. That is why the reputation management of a tourist destination needs to be improved at all levels.

But it should be noted that the tourism industry is currently experiencing the deepest crisis with a drop in international arrivals by $74 \%$ in 2020 . The collapse of international travel is estimated at a loss of export revenues of 1.3 trillion. Dol. US, more than 11 times the losses recorded during the global economic crisis of 2009.

The overall prospects for recovery in 2021 seem to have deteriorated. Currently, $50 \%$ of respondents expect that the recovery will take place only in 2022 compared to $21 \%$ in October 2020. The remaining half of respondents still see a potential rebound in 2021, although below the expected results of the survey conducted in October 2020 (79 \% expected a recovery in 2021) according to the tourist barometer [2].

And one of the conditions for the successful existence and development of a tourist destination is the need to constantly monitor the level of its competitiveness by various criteria to identify strengths and weaknesses and, accordingly, to develop tactics and strategies for industry development at different levels of management.

The purpose and objectives of the article to determine the process of evaluating a tourist destination.

\section{Presentation of the main material of the study and the results obtained}

The basis of the tourist destination competitiveness management system is a quality tourist product, which is the main purpose of the tourist destination competitiveness management system, and all management decisions should be evaluated in terms of their impact on this indicator [5, p. 158].

The basis for the formation of management of the competitiveness of a tourist destination is a model of integration of interconnected functional blocks of management (education, research and development, economic and legal support, marketing) in a single independent economic process (Fig. 1), which creates competitive advantages of the destination management decisions.

The mechanism of functioning of the system determines the location of each element of the system, ie sets its hierarchy. The mechanism of the proposed system (Fig. 1) has a complex structure (principles, goals, management tasks, functions, methods, competencies, mechanisms), represented by the interaction of different blocks.

The main element of the infographic system for managing the competitiveness of the destination (Fig. 1) is the mechanism of formation of competitive advantages of the destination. The mechanism of our proposed competitiveness management system is aimed at maximizing the competitiveness of the tourist product and meeting the needs of the population by optimizing the structure of the distribution of tourist resources in the destination. 
O. Chernega

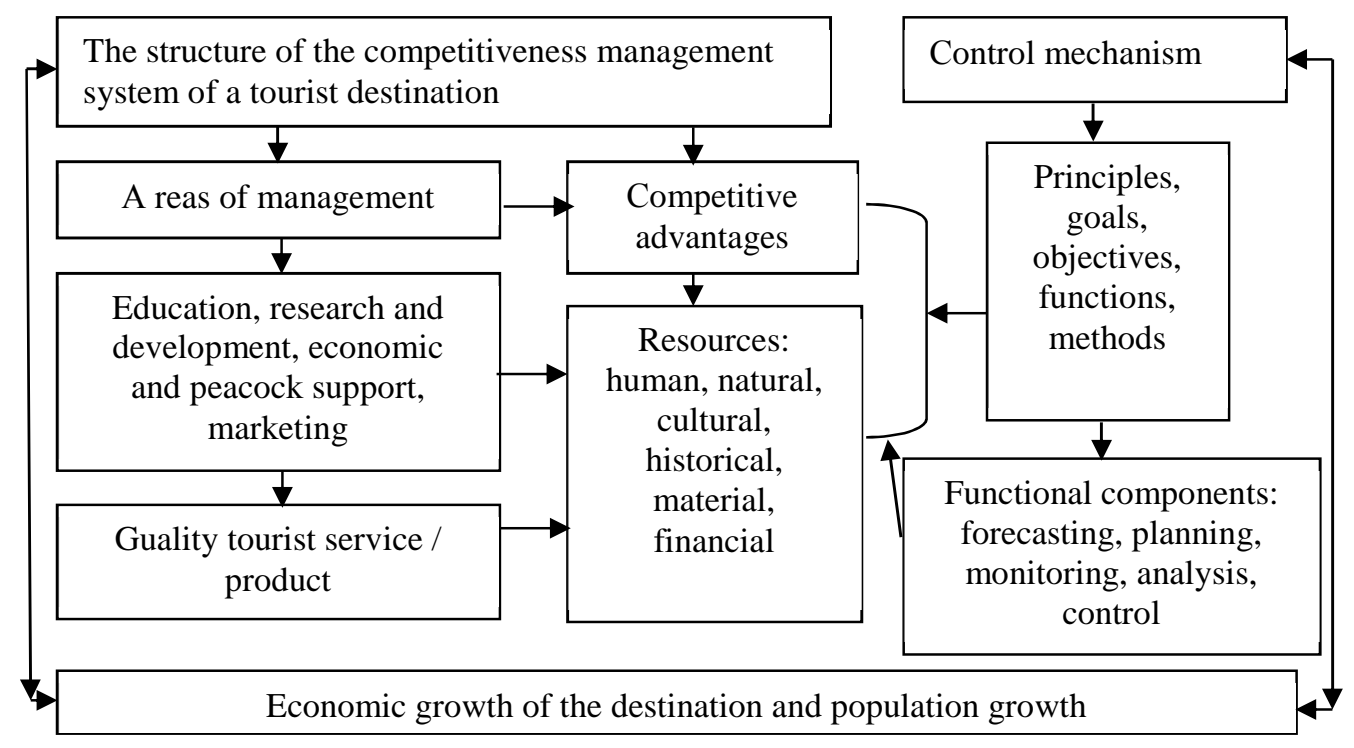

Fig. 1 Infoology of the tourist destination competitiveness management system

Source: developed by the author

The mechanism highlights the structural interaction of functional components (forecasting, planning, organization, monitoring, analysis and control), which allows to improve the relationship of system elements while increasing the positive impact of external and internal factors. [10]

The most widely presented in the literature is the cluster concept of competitiveness of the territory, which is based on the fact that the competitiveness of the territory depends on the presence of a cluster of interconnected industries. The concept is based on the system of determinants of international competitiveness of $\mathrm{M}$. Porter, which together are called by him a cluster of interconnected industries. M. Porter defines a cluster as a geographically close group of related companies and interacting institutions in a specific area related to communities and complementarities. According to M. Porter, the presence of competing firms, industries, suppliers of resources and consumers in the cluster gives the economy of a region or a country the ability to compete internationally. The cluster type of economic organization allows to create integrated competitive advantages due to the following factors:

- creation of general and specialized production infrastructure taking into account the optimal spatial location of productive forces and factors of production;
- creating conditions for economic growth and minimizing costs through the production concentration of the economy;

- creation of favorable conditions for the development of both specialization and infrastructure industries;

- stimulation of competition and innovative activity of business structures within the cluster, increase the efficiency of their activities, increase productivity;

- creating favorable conditions for attracting investment and skilled labor.

The term "cluster" is used in many sciences. In a general sense, a cluster is a set of elements combined on a certain basis into a structure that has certain (common) properties. The definition of this feature in a large and complex system is one of the main and complex points and, as a rule, is a subjective factor that depends on the direction of the study and the researcher. And the more complex the system, the more difficult it is to determine this feature by which to combine elements into a given class (cluster). But, of course, the more correctly this feature is defined, the better (more adequate) the result will be, ie the cluster will be formed more correctly.

In the scientific economic literature, there are many well-established approaches in determining the attribute by which the elements are combined 


\section{Assessment of the competitiveness of the tourist destination}

into a class (cluster), but the question of determining the "proximity" of the elements remains open.

The idea of clustering is the basis for the development of modern strategies for tourism development. A tourism cluster is a group of interconnected resources, factors, enterprises concentrated on a certain territory, which are necessary or desirable for the development of a certain type of tourism, contribute to meeting the needs of tourists depending on the motive of travel [11].

As can be seen from the definition, the concept of cluster is consistent with the concept of tourist destination, ie, the destination may consist of different clusters. For a qualitative study of this area it is necessary to apply the method of decomposition, ie in a tourist destination to allocate its components - tourist clusters. This is necessary because different destinations and types of tourism can develop in the destination, which, as a rule, mutually exclude the use of the same infrastructural resources of the territory.

For example, youth tourism, and leisure tourism - family tourism (business tourism, education, health, etc.; you can continue this list of types of tourism). In this case, there are conflicts of interest of different segments of tourists. This situation is observed, for example, in a known area (destination).

Sunny beach in Bulgaria. Sunny Beach was originally positioned as a destination for family vacations. At the moment, this area is being re-profiled (positioned) for the development of youth tourism and, of course, is not attractive for people who come to rest with children. Thus, as a tourist destination of sports and youth orientation, this area has not yet been formed, but loses its appeal to those tourists who created the main segment and defined this area as a tourist destination. In this situation, there may be an outflow of tourists in this segment, and a new segment will not be formed, because at first this area had a completely different attraction and will require a lot of resources to form this area as a tourist destination.

Therefore, the territory can and should have many tourist clusters, depending on the type and directions of tourism development, which are determined by the proximity indicator, which will form these clusters.
The division of a large destination into smaller segments that have different attractions (resources, infrastructure, socio-economic, political situation, etc.) allows you to better study and manage economic regions, increase their efficiency, competitiveness.

The tourism industry includes various companies that do not necessarily compete directly with each other. The relationship between competition and economic coordination of tourism market participants is extremely important, because the successful development of tourism in the destination involves close cooperation between different market participants who do not compete directly.

One of the most important tasks is to increase the competitiveness of the tourist destination. The competitiveness of a tourist destination must be considered using the destination life cycle model, taking into account the competitive profile at each of these stages. A.R. As part of the task of managing competitive advantage in the implementation of industrial policy at the meso level, Safiullin proposes to use three stages (phases) of managing competitive advantage:

- configuration of the competitive profile,

- analysis of competitive positions,

- development and preparation for implementation of the program of strategy of development of competitive advantages [12]

When considering the issues of increasing the competitiveness of a tourist destination, it is proposed to introduce three more stages:

- construction of the desired (ideal) competitive profile of the destination taking into account its life cycle,

- assessment of the costs of achieving the desired and actually achievable competitive profile,

- development of the project of formation of really achievable competitive profile.

When considering competition between destinations, it should be noted that one of the most significant forces is the influence of the local population on the development of tourism.

To date, there are a wide variety of theories for assessing the level of competitiveness of the tourism industry in general, and tourist destinations in particular, most of which are based on general industry models of competitiveness or models of competitiveness of the national economy as a whole. 


\section{O. Chernega}

However, a number of modern tourism researchers have developed their own tourism models for assessing the level of competitiveness, among which the Ritchie-Crouch model is important, which was proposed by scientists in 1999, and later in 2003 was supplemented.

Table 1

\section{Component assessments of the level of competitiveness of a tourist destination according to the Ritchie-Crow model}

\begin{tabular}{|c|c|c|}
\hline № $\mathrm{p} / \mathrm{p}$ & Group of indicators & Indexes \\
\hline \multirow{6}{*}{1.} & \multirow{6}{*}{$\begin{array}{l}\text { Qualification and reinforcement } \\
\text { indicators }\end{array}$} & 1. Destination location \\
\hline & & 2. Tourist security and protection system \\
\hline & & 3. Cost and price of a tourist destination \\
\hline & & 4. Interdependence \\
\hline & & 5. The image of a tourist destination \\
\hline & & 6. Capacity of a tourist destination \\
\hline \multirow{8}{*}{2.} & \multirow{8}{*}{$\begin{array}{c}\text { Policy, planning and } \\
\text { development of a tourist } \\
\text { destination }\end{array}$} & 1. Tourist destination definition system \\
\hline & & 2. Philosophy and tourist values \\
\hline & & 3. A look at a tourist destination \\
\hline & & 4. Positioning and branding \\
\hline & & 5. Development \\
\hline & & 6. Analysis of the competitive environment \\
\hline & & 7. Monitoring and evaluation \\
\hline & & 8. Audit of the state of the tourist destination \\
\hline \multirow{9}{*}{3.} & \multirow{9}{*}{ Tourist destination management } & 1. Organization \\
\hline & & 2. Marketing \\
\hline & & 3. Quality of services and experience \\
\hline & & $\begin{array}{l}\text { 4. Information system and research of tourist destination } \\
\text { development }\end{array}$ \\
\hline & & 5. Human resource management \\
\hline & & 6. Finance and venture capital \\
\hline & & 7. Visitor management \\
\hline & & 8. Management of tourist resources \\
\hline & & 9. Crisis management \\
\hline \multirow{7}{*}{4.} & \multirow{7}{*}{$\begin{array}{l}\text { The main resources and objects } \\
\text { of attraction of tourists }\end{array}$} & 1. Geographical conditions and climate \\
\hline & & 2. Cultural and historical resources \\
\hline & & 3. A set of activities developing within a tourist destination \\
\hline & & 4. Special tourist events \\
\hline & & 5. Entertainment system \\
\hline & & 6. Tourist superstructure \\
\hline & & 7. Marketing links \\
\hline \multirow{6}{*}{5.} & \multirow{6}{*}{ Supporting factors and resources } & 1. Infrastructure \\
\hline & & 2. Availability of a tourist destination \\
\hline & & 3. Service resources \\
\hline & & 4. Hospitality system \\
\hline & & 5. Entrepreneurial environment \\
\hline & & 6. Political will \\
\hline
\end{tabular}

Source: [8]

The Ritchie-Crow model is based on the concept that the competitiveness of a tourist destination is determined by the level of resource availability (comparative advantage), as well as its ability to allocate resources (competitive advantage). In addition, the model recognizes the impact of 
competitive microenvironment and factors of the global macroenvironment (the state of the global economy, terrorism, cultural and demographic trends, etc.) on the state and development of the tourist destination.

This model of competitiveness can be adapted to the peculiarities of the functioning of any tourist destination. It is very flexible and simple enough to assess the level of competitiveness of a tourist destination in order to develop an effective policy for the management of the tourism industry as a whole. However, one of the disadvantages of this model is its certain abstractness and the impossibility of quantitative measurement of all its components [8].

M. Porter's Diamond Model is often mentioned in Ukrainian scientific sources on competitiveness issues. The model is a component of the theory of structural competitiveness of nations, combines and organizes the main factors that allow countries (large regions), and therefore their businesses to be successful in certain sectors of the economy. Factors are grouped into four main interrelated categories and form a system capable of self-reinforcement, in which the level of change in each group depends to a greater or lesser extent on changes in other groups [13].

, 1 group. Strategy, structure and competition of firms. The existence of strong industries helps to stimulate increased competitiveness in the sector. Inter-firm competition forces all firms in the sector to lower prices, improve quality, design new services and apply new creative strategies aimed at increasing market share.

2 groups. Demand conditions, in particular its size and nature, can put pressure on business and thus ensure the innovation of goods and services.

, 3 groups. Related support industries. We are talking about the presence or absence of suppliers from other market sectors that cooperate or provide services to companies in the tourism market. These providers are considered a source of benefits if they provide their services economically and efficiently.

, 4 groups. Factor conditions. Unlike his predecessors, M. Porter argues that key factors of production are created, not inherited. Such factors include human resources, capital and infrastructure and argue that these factors form a stable competitive advantage, because it is extremely difficult to copy them.

The optimal combination of these factors is possible, according to $\mathrm{M}$. Porter, in the cluster the geographical concentration of interdependent companies, suppliers of goods and services and associated organizations in a particular industry [13].

It is this opinion of the American specialist that formed the basis of numerous scientific researches of Ukrainian scientists devoted to tourism. In the works of P V Hudzia, I. V. Berezhno, I. Yu. Shvets and their followers developed conceptual principles, models, methods of creation and development of tourist and recreational clusters in Ukraine $[1,6,14]$. In addition, several local programs for the development of tourist and resort-recreational clusters are being implemented in Ukraine.

Meanwhile, foreign scientific schools tend to consider the ideas of M. Porter in the context of existing tourist destinations, developing on their basis specific "tourist" models. According to G. Crouch and J. Richie, who in the late 20th century for the first time made a theoretical justification for the market development of tourism, in order to ensure long-term competitiveness of a tourist destination, it is necessary to have both comparative and competitive advantages [19]. Researchers explain that in tourism as comparative advantages are mainly natural resources (climate, landscapes, flora, fauna, etc.), while competitive advantages include elements of tourist infrastructure (hotels, historical and cultural monuments, transport network), events, quality local government, marketing effectiveness, qualification of tourism workers, government policy and local government. In other words, rich natural resources alone are not a sufficient guarantee of long-term success. The destination must also be able to use its assets efficiently, providing value-added production.

In the domestic scientific literature, the competitiveness of the destination is directly related to the quantitative and qualitative parameters of the resource base, the ability of local enterprises to provide the necessary goods and services to tourists of a certain quality, transport accessibility. Western scholars go further, linking competitiveness not only with the quality or variety of the tour product, but also with the difference in prices in combination 


\section{O. Chernega}

with exchange rate fluctuations, productivity, the degree of coordination of local market actors, which in turn affects attractiveness or lack thereof in the destination. In addition, competitiveness is also defined as "the ability of a destination not only to maintain its position in the market through the sharing of resources by many entities, but also to strengthen these positions over time" [18].

Consider in more detail the Crouch-Richie model, which is not only the result of research in the field of tourism for more than ten years, but also a response to the growing competition between tourist destinations around the world. The model was launched in 1993 and was initially purely descriptive. Later, in response to attempts to adapt to changes in the competitive environment, it evolved and became more complicated. Thus, according to the authors of the model, competitiveness can be considered as a set of factors, the first of which is, of course, the attractiveness of the destination.

There are a number of factors that play an important role in attracting tourists to the destination, such as its appearance, culture, action, entertainment, as well as the so-called superstructure, which includes all public and private organizations that regulate, develop and coordinate tourism.

The second group of factors traditionally consists of resources and infrastructure, without which the development of tourism is impossible, and the third - the management system formed in the destination, including marketing, existing initiatives, organizational structure, information systems, human resources, quality of service, without which it is impossible exploitation of factors of the second group. The fourth group of factors is closely related to the third, because the authors of the model believe that it includes the policy of planning and development of the destination, which forms the environment of its existence.

Finally, the latter group are constraints and amplifiers that can affect the competitive potential of tourist destinations, such as security, information, image, brand, value for money.

American researcher S. Hassan adds to the model two more factors that affect the system, namely the competitive environment within the destination, ie the factors that determine competition between local tourism market, the media, financial institutions, etc. and the competitive environment at the macro level - the state of the environment, demographic trends, the economic situation in the country and the world, the introduction of new technologies, etc. [18].

Following the work of Richie and Crouch at the beginning of the 21st century, the works of the Australian researcher L. Dwyer and the Korean scientist C. Kim [12,13] appeared, who proposed an improved version of the Richie and Crouch model and thus tried to better take into account connections between different factors within the destination. In addition, the authors of the model came up with a rather revolutionary opinion that the determinants of competitiveness for each destination can be very different, so the destination should seek an individual approach to strengthening and developing tourism competitiveness, rather than adapting a single universal policy or strategy. It is necessary to pay attention to the peculiarities of the application of the model of destination competitiveness, the relevance and importance of its key variables at different stages of the life cycle [12].

Thus, according to this model, the determining factors for the competitiveness of a tourist destination can be considered [12]:

1. Inherited resources of the area where the destination is located, including natural and historical and cultural resources, because they determine the primary interest of tourists to the destination

2. Specially created for the development of tourism resources, which include:

- tourist infrastructure facilities, including accommodation, food, transport, tour operators and travel agents, car rental, etc.;

- special sports and leisure activities;

- leisure and entertainment facilities that are not specialized in tourism, but can attract tourists;

- trade establishments.

3. Additional factors and resources that can provide a basis for sustainable competitiveness of tourist destinations. This subgroup includes:

- institutions of general infrastructure: roads, airports, bus and railway networks, water supply, telecommunications, electricity, financial system, etc.;

- generally accepted on the territory of service quality standards, which in themselves can both strengthen the competitive advantages of the 
destination and weaken them. It is important that the average level of service quality corresponds to this in the imagination of tourists and in their previous tourist experience. In this case, it is possible that a tourist destination with high quality standards but also high, according to the consumer, these of us, will be less competitive than where the quality leaves much to be desired, but the prices are reasonable for potential tourists;

- availability of the destination - another key factor of competitiveness, which includes the availability of the visa procedure, airport capacity, etc.;

- hospitality of the local population according to the authors, one of the key social factors influencing the competitiveness of tourist destinations;

- external relations - a category that covers trade relations, migration flows, cultural relations, etc.

4. Destination management: this group includes those factors that can make resources more attractive and improve the quality and efficiency of other factors.

In addition, these factors allow destinations to adapt quickly to situational changes. According to the model, destination management includes five activities:

- destination marketing management: this category means activities for the development of new products, these new policies, as well as the creation of appropriate distribution channels. It also includes research, market segmentation and destination image building. This task must be agreed with the public and the private sector of the tourism business;

- destination planning and development policy, ie norms, laws and guidelines, goals, objectives and strategies that together contribute to the realization of the interests of enterprises and individuals in the destination;

- organization of destination management, in particular coordination between public and private sectors, provision of information on various aspects of destination tourism development, strategic control;

- development of human resources, because they play an important role in increasing the competitiveness of tourist destinations. The training system and the average level of qualification of tourist personnel determine the possible degree of adaptation to technological, organizational and social changes in the environment;

- environmental management: management of natural resources, including - education of local people in understanding the importance of preserving the environment is a key factor in ensuring the competitiveness of tourist destinations in the long run, because in tourism more than in any other industry, product quality is closely related to the quality of the environment.

5. Situational conditions are able to define the boundaries or increase the competitive potential of the destination. These include:

- location of the destination, ie geographical location relative to the leading territorial markets for the supply of tourists;

- competitiveness of the microenvironment opportunities and resources of enterprises and organizations located in the destination, their strategies and alliances;

- macro environment of the destination;

- security: political instability, crime, terrorism, disease, etc.;

- prices, or the total cost of the "tourist experience".

6. The nature of demand for the tourist product of the destination, the characteristics of the target segments [9].

\section{Conclusions}

Thus, a market economy involves the study of competitiveness in any field of activity, regardless of ownership and scale of activity. Competitive can be considered a tourist destination that is able to produce tourist products that are in demand in domestic and foreign markets, and on this basis to ensure economic growth and improve the welfare of the local population. Competitiveness of a tourist product is the main condition that distinguishes between the concepts of "tourist region" and "tourist destination". To determine the level of competitiveness of a tourist destination, scientific models are used.

\section{References}

1. Berezhna I. V. (2005). National priorities and regional determinants of socio-economic growth (on the materials of the Autonomous Republic of Crimea) Extended abstract of Doctor's thesis. Lviv: 


\section{O. Chernega}

NAS of Ukraine. In-t region. Research [in Ukrainian].

2. World Tourism Barometer, Retrieved from https://www.e-unwto.org/doi/epdf/10.18111/ wtobarometerrus.2021.19.1.1 (access date (01.06.21))

3. World Tourism Organization, Retrieved from http://www2.unwto.org (accessed March 18, 21)

4. World Economic Forum, Retrieved from https://www.weforum.org/(accessed March 18, 21)

5. Golovchan A. I. (2009). Theoretical and methodological approaches to defining the essence of tourist destinations and their management. Trade and market of Ukraine, 27, 157-161. [in Ukrainian].

6. Hudz P.V. (2003). The mechanism of development of resort and recreational areas in modern conditions. Extended abstract of Doctor's thesis. Donetsk: National Academy of Sciences of Ukraine. Institute of Economic Law research. [in Ukrainian].

7. State Statistics Service of Ukraine Retrieved from http://www.tourism.gov.ua (access date 01.06.21) [in Ukrainian].

8. Dubenyuk-Panayotopoulou, Ya.A. (2015). Features of assessing the level of competitiveness of a tourist destination. actual problems of science and education: Collection of materials of the XVII final scientific-practical conference of MSU teachers. (pp. 101-102). Mariupol:MSU. [in Ukrainian]

9. Zabaldina, Y. B. (2011) Suchasni pidkhody do otsinky konkurentospromozhnosti turystychnykh destynatsiy [Modern approaches to assessing the competitiveness of tourist destinations]. Formuvannya rynkovykh vidnosyn v Ukrayini - Formation of market relations in Ukraine, 12, 165-168 [in Ukrainian].

10. Kozhukhivska R. B. (2020). The management of competitiveness of the tourist destination. Eastern europe: economy, business and governance, 1 (24), 175-180 [in Ukrainian]. https://doi.org/10.32782/ easterneurope.24-25

11. Morozova N. S., \& Morozov M. A. (2010). Entrepreneurship and competition in tourism. Moscow: RosNOU. [in Russian].

12. Saffiulin A. R. (2014). Methodology of management of competitive advantages at the meso level. Kazan: KSU Publishing House. [in Russian].

13. Porter M. (2005). Competitiveness. Moscow: Williams. [in Russian].

14. Shvets I. Yu. (2009) Regional management of competitiveness of tourist services: methodology and practice. Extended abstract of Doctor's thesis. Kyiv: Council for study. product. Forces of Ukraine of the National Academy of Sciences of Ukraine. [in Ukrainian].

15. State Agency for Tourism Development of Ukraine. Retrieved from https://www.tourism.gov.ua/ (access date 09.03.21) [in Ukrainian].

16. Dwyer, L. (2001). Destination competitiveness: Development of a model with application to Australia and the Republic of Korea. Unpublished Report. University of Western Sydney, Sydney

17. Dwyer, L. \& Kim, C. (2003). Destination competitiveness: determinants and indicators. Current Issues in Tourism, 6(5): 369-414. https://doi.org/10. 1080/13683500308667962

18. Hassan, S. (2000). Determinants of Market Competitiveness in an environmentally sustainable tourism industry. Journal of Travel Research, 38(3), 239-245 https://doi.org/10.1177/004728750003800305

19. Ritchie, J. R. B., \& Crouch, G. I. (2000). The Competitive Destination: A Sustainability Perspective. Tourism Management, 21(1), 1-7. 